\title{
Insulin/IGF-1 enhances intestinal epithelial crypt proliferation through PI3K/Akt, and not ERK signaling in obese humans
}

\author{
Weinan Zhou ${ }^{1}$ (D, Blair M Rowitz ${ }^{2}$ and Megan J Dailey ${ }^{1}$ (1) \\ ${ }^{1}$ Department of Animal Sciences, University of Illinois at Urbana-Champaign, Urbana, IL 61801, USA; ${ }^{2}$ Carle Illinois College of Medicine, \\ Carle Foundation Hospital, Urbana, IL 61801, USA \\ Corresponding author: Megan J Dailey. Email: mdailey5@illinois.edu
}

\footnotetext{
Impact statement

This study investigates if insulin or insulinlike growth factor-1 (IGF-1) induces intestinal epithelial proliferation in humans, and if insulin and IGF-1 receptor signaling is involved in this process in obesity. Although obesity-induced high levels of insulin and IGF-1 in the stem cell niche are found to impact the proliferation of intestinal epithelial stem cells in rodents, we are the first to investigate this effect in humans. We found that insulin and IGF-1 enhanced the proliferation of intestinal crypts (including stem cells and other crypt cells) isolated from obese humans, and PI3K/ Akt, and not ERK signaling was involved in insulin or IGF-1-induced proliferation.

The imbalance in signaling between $\mathrm{PI}$ KK/Akt and ERK pathways may point to a pathway-specific impairment in insulin/ IGF-1 receptor signaling. We propose that this may contribute to reciprocal relationships between insulin/IGF-1 receptor resistance and intestinal epithelial proliferation that leads to abnormal tissue renewal and function.
}

\begin{abstract}
The intestinal epithelium is continuously regenerated through proliferation and differentiation of stem cells located in the intestinal crypts. Obesity affects this process and results in greater stem cell proliferation and altered tissue growth and function. Obesity-induced high levels of insulin and insulin-like growth factor-1 in the stem cell niche are found to impact proliferation in rodents indicating that insulin and insulin-like growth factor-1 receptors may play a role in modulating intestinal epithelial stem cell proliferation. To determine whether insulin or insulin-like growth factor-1 can induce proliferation in human intestinal epithelial stem cells, and if two downstream insulin and insulin-like growth factor-1 receptor signaling pathways, PI3K/Akt and ERK, are involved, we used primary small intestinal epithelial crypts isolated from obese humans and investigated (1) the effect of insulin or insulin-like growth factor-1 on crypt proliferation, and (2) the effect of insulin and insulin-like growth factor-1 signaling inhibitors on insulin or insulin-like growth factor-1-induced proliferation. We found that insulin and insulin-like growth factor-1 enhanced the proliferation of crypt cells, including intestinal epithelial stem cells. Inhibition of the PI3K/Akt pathway attenuated insulin and insulin-like growth factor-1-induced proliferation, but inhibition of the ERK pathway had no effect. These results suggest that the classical metabolic PI3K pathway and not the canonical proliferation ERK pathway is involved in the insulin/insulin-like growth factor-1-induced increase in crypt proliferation in obese humans, which may contribute to abnormal tissue
\end{abstract}

renewal and function.

Keywords: Insulin, insulin-like growth factor-1, intestinal epithelium, proliferation, obesity

Experimental Biology and Medicine 2018; 243: 911-916. DOI: 10.1177/1535370218785152

\section{Introduction}

The intestinal epithelium plays important roles in nutrient absorption, satiety hormone release, and immune barrier function. In order to ensure proper tissue actions are maintained, the cells are continuously regenerated through proliferation and differentiation of intestinal epithelial stem cells (IESCs) located in the intestinal crypts. Obesity affects this process and results in changes in tissue growth and function. ${ }^{1}$ In particular, obesity increases IESC number and proliferation, total epithelial cell number, villus height or crypt depth in vivo, and causes lasting effects in IESCs, such that isolated IESCs from obese compared to lean mice grow at different rates in vitro., ${ }^{2,3}$ These changes are associated with many negative adverse consequences in tissue function. The increase in proliferation leads to a greater chance of mutations and less DNA repair mechanisms which can lead to tumor growth and cancer, ${ }^{4-6}$ and may be the cause of the obesity-associated increase in the risk of intestinal cancers. ${ }^{7,8}$ Aberrant proliferation of IESCs specifically, and not other intestinal epithelial cell types, 
also underlies both small intestinal ${ }^{9}$ and colon $^{9-11}$ cancer. Moreover, greater proliferation leads to greater growth of the tissue, which is reflected as an increase in differentiated cell number and not just an increase in the number of stem or progenitor cells. ${ }^{3}$ In particular, the increase in tissue size is reflected by an obesity-induced increase in enterocyte number. ${ }^{12-14}$ This increase in enterocyte number reflects the greater absorptive capacity of the epithelial tissue in obesity, a quality that is not desirable and could result in greater body weight gain. ${ }^{13,15}-17$ Taken together, these findings suggest that obesity may alter the proliferation, growth and function of the intestinal epithelial tissue, and increase the risk of intestinal cancers through the modulation of IESCs. It is unclear, though, the mechanism underlying the obesity-induced alterations in IESCs.

Obesity induces high levels of circulating insulin and insulin-like growth factor-1 (IGF-1) released from the pancreas and liver, respectively, and high levels of local intestinal IGF-1 released from the mesenchymal cells that underlie the IESCs. ${ }^{18}$ Insulin receptor isoforms A and B and IGF-1 receptor are expressed in IESCs. ${ }^{3}$ Obesity-induced high levels of insulin and IGF-1 in the stem cell niche are found to impact proliferation in rodents indicating that insulin and IGF-1 receptors may play a role in modulating IESC proliferation. ${ }^{3,19}$ Moreover, insulin and IGF-1 receptor resistance are a hallmark of obesity that can be driven by an imbalance between or abnormal signaling within two downstream pathways, phosphatidylinositol 3-kinase (PI3K) and extracellular signal-regulated kinases (ERKs), in non-intestinal epithelial tissues. ${ }^{20-22}$ It is unknown, though, if insulin or IGF-1 induces IESC proliferation in humans, and if PI3K/Akt and ERK pathways are involved in insulin or IGF-1-induced proliferation in obesity. Thus, we used primary small intestinal epithelial crypts, which include IESCs and other crypt cells, isolated from obese humans, and investigated proliferation in response to insulin or IGF-1, and insulin and IGF-1 receptor signaling inhibitors (i.e. PI3K/Akt pathway inhibitor Wortmannin, ERK pathway inhibitor PD98059).

\section{Materials and methods}

\section{Human tissue}

Human intestinal mucosal tissue samples $(1 \times 1$ inch) were obtained from tissue normally discarded from obese patients undergoing Roux-en-Y gastric bypass surgery. All procedures were approved by the Institutional Review Board (IRB) at Carle Foundation Hospital and the University of Illinois at Urban-Champaign (IRB protocol \#16068). Informed consent was obtained from the subjects and the privacy rights of the subjects were observed.

\section{Crypt isolation and culture}

Intestinal crypts were isolated as previously described. ${ }^{23,24}$ Briefly, the villi were scraped off from the intestinal mucosal tissue with a curved forceps. The tissue was cut into 2-4 mm pieces with scissors and washed 5-10 times with cold $1 \times$ PBS until the supernatant was almost clear. Tissue fragments were incubated with $2 \mathrm{mM}$ EDTA
(Fisher Scientific, Pittsburgh, PA) chelation buffer $(1 \times$ PBS containing $43.4 \mathrm{mM}$ sucrose (Fisher Scientific) and $54.9 \mathrm{mM}$ D-sorbitol (Fisher Scientific)) and gently rocked at $4^{\circ} \mathrm{C}$ for $30 \mathrm{~min}$. After removal of EDTA, tissue fragments were vigorously washed with cold chelation buffer for eight times. The supernatant was then collected and centrifuged at $200 \mathrm{~g}$ at $4{ }^{\circ} \mathrm{C}$ for $5 \mathrm{~min}$. Freshly isolated crypts were embedded in Matrigel (Corning, Corning, NY) at 200 crypts $/ 10 \mu \mathrm{L}$, seeded on 96-well plates (replicates of 4 wells per group), and incubated in crypt culture medium (Advanced DMEM/F12 (Gibco, Grand Island, NY) containing $2 \mathrm{mM}$ GlutaMax (Gibco), 10 mM HEPES (Gibco), $100 \mathrm{U} / \mathrm{mL}$ penicillin-streptomycin (Gibco), 1× N2 (Gibco), 1× B27 (Gibco), $1 \mathrm{mM}$ N-Acetyl-L-cysteine (Sigma-Aldrich, St. Louis, MO), 1\% bovine serum albumin (Sigma-Aldrich), $10 \mathrm{mM}$ nicotidamide (Sigma-Aldrich), $50 \mathrm{ng} / \mathrm{mL}$ EGF (Gibco), 100 ng/mL Noggin (PeproTech, Rocky Hill, NJ), $500 \mathrm{ng} / \mathrm{mL}$ R-Spondin-1 (PeproTech), $10 \mathrm{nM}$ gastrin (Sigma-Aldrich), $10 \mu \mathrm{M}$ SB 202190 (Sigma-Aldrich), 500 $\mathrm{nM}$ A 83-01 (Sigma-Aldrich), and $100 \mathrm{ng} / \mathrm{mL}$ Wnt-3A $(\mathrm{R} \& \mathrm{D}$, Minneapolis, $\mathrm{MN})$ ) overnight with $5 \% \mathrm{CO}_{2}$ at $37^{\circ} \mathrm{C}$.

\section{Cell proliferation measurements}

For the determination of proliferation in response to insulin or IGF-1, crypt cultures were changed to insulin and IGF-1-free crypt culture medium (DMEM/F12 (Gibco) containing $2 \mathrm{mM}$ GlutaMax, $10 \mathrm{mM}$ HEPES, $100 \mathrm{U} / \mathrm{mL}$ penicillin-streptomycin, homemade N2 (DMEM/F12 containing $100 \mu \mathrm{g} / \mathrm{mL}$ transferrin, Holo (Sigma-Aldrich), $6.3 \mathrm{ng} / \mathrm{mL}$ progesterone (Sigma-Aldrich), $16.11 \mu \mathrm{g} / \mathrm{mL}$ putrescine (Sigma-Aldrich), and $5.2 \mathrm{ng} / \mathrm{mL}$ selenite (Sigma-Aldrich)), $1 \times$ B27, minus insulin (Gibco), $1 \mathrm{mM}$ N-Acetyl-L-cysteine, $1 \%$ bovine serum albumin, $10 \mathrm{mM}$ nicotidamide, $50 \mathrm{ng} / \mathrm{mL}$ EGF, $100 \mathrm{ng} / \mathrm{mL}$ Noggin, $500 \mathrm{ng} / \mathrm{mL}$ R-Spondin-1, $10 \mathrm{nM}$ gastrin, $10 \mu \mathrm{M}$ SB 202190, $500 \mathrm{nM}$ A 83-01, and $100 \mathrm{ng} / \mathrm{mL}$ Wnt-3A), and incubated with $5 \% \mathrm{CO}_{2}$ at $37^{\circ} \mathrm{C}$ for one day. A subset of crypt cultures were then incubated in insulin and IGF-1-free crypt culture medium with $25 \mathrm{mM}$ HEPES (control) or with different concentrations of insulin (Santa Cruz Biotechnology, Dallas, TX) $(0.1,10,100 \mathrm{nM})$ with $5 \% \mathrm{CO}_{2}$ at $37^{\circ} \mathrm{C}$ for additional one day. Another subset of crypt cultures were then incubated in insulin and IGF-1-free crypt culture medium with $1 \times$ PBS (control) or with different concentrations of IGF-1 (R\&D) $(0.1,10,100 \mathrm{nM})$ with $5 \% \mathrm{CO}_{2}$ at $37^{\circ} \mathrm{C}$ for additional one day. These concentrations and time points were chosen based on previously published experiments testing insulin or IGF-1-induced proliferation of intestinal epithelial cells. $^{3,19,25}$ Cell proliferation was then measured using Cell Proliferation Reagent WST-1 (Roche Diagnostics, Indianapolis, IN) according to the manufacturer's instructions. Proliferation was then measured using the WST-1 assay in response to the PI3K/Akt pathway inhibitor, Wortmannin (Cell Signaling Technology, Danvers, MA), or the ERK pathway inhibitor, PD98059 (Cell Signaling Technology). After one day incubation in insulin and IGF1-free crypt culture medium, crypt cultures were pretreated with DMSO (control) or with different concentrations of Wortmannin $(0.2,1 \mu \mathrm{M})$ or PD98059 $(20,50 \mu \mathrm{M})$ for $1 \mathrm{~h}$, 
and then incubated with $10 \mathrm{nM}$ insulin or IGF-1 for additional one day with $5 \% \mathrm{CO}_{2}$ at $37^{\circ} \mathrm{C}$. These concentrations and time points were chosen based on previously published experiments testing Wortmannin or PD98059induced changes in intracellular signaling of intestinal epithelial cells and other cell types. ${ }^{25-27}$ Cell proliferation was then measured using Cell Proliferation Reagent WST-1.

\section{Data analysis}

Data are expressed as Mean \pm SEM. Differences between groups were analyzed using a one-way ANOVA followed by a Fisher's LSD post hoc test. $P<0.05$ was considered statistically significant.

\section{Results}

\section{Insulin and IGF-1 enhanced crypt proliferation}

Crypt proliferation was increased in the $0.1,10$, and $100 \mathrm{nM}$ insulin conditions compared with the control group. Specifically, proliferation was increased in the 10 and $100 \mathrm{nM}$ insulin conditions compared with the control and $0.1 \mathrm{nM}$ groups, and in the $0.1 \mathrm{nM}$ insulin condition compared with the control group (Figure $1(\mathrm{a}) ; P<0.05$ ). Moreover, proliferation was increased in the $0.1,10$, and $100 \mathrm{nM}$ IGF-1 conditions compared with the control group (Figure 1(b); $P<0.05$ ).

\section{Inhibition of PI3K/Akt pathway attenuated insulin/ IGF-1-induced proliferation, but inhibition of ERK pathway had no effect}

Crypt proliferation was decreased in the 0.2 and $1 \mu \mathrm{M}$ Wortmannin conditions compared with the control group, and in the $0.2 \mu \mathrm{M}$ Wortmannin condition compared with the $1 \mu \mathrm{M}$ Wortmannin group (Figure 2(a); $P<0.05$ ). Moreover, proliferation was decreased in the $1 \mu \mathrm{M}$ Wortmannin condition compared with the control and $0.2 \mu \mathrm{M}$ Wortmannin groups (Figure 2(b); $P<0.05$ ). However, there were no differences in the insulininduced (Figure 2(c)) and IGF-1-induced (Figure 2(d)) proliferation after PD98059 application.

\section{Discussion}

The aim of this study was to investigate the effect of insulin or IGF-1 on crypt proliferation and the effect of insulin and IGF-1 signaling inhibitors on insulin or IGF-1-induced proliferation in IESCs and other crypt cells isolated from obese humans. The major findings were (1) insulin and IGF-1 enhanced the proliferation of intestinal crypts, and (2) PI3K/Akt, and not ERK signaling, was involved in insulin/IGF-1-induced proliferation.

Despite extensive research on the roles of insulin and IGF-1 in coordinating systemic growth and development with nutrient homeostasis in normal versus obese conditions, little is known about their roles in controlling somatic stem cells and tissue regeneration. Non-diabetic obese humans and diet-induced obese rodent models exhibit high circulating levels of insulin and IGF-1, and local release of IGF-1 from mesenchymal cells that underlie the IESCs. ${ }^{3,18,28}$ These factors have been found to impact IESC proliferation in rodents and is the underlying mechanism responsible for the differential IESC proliferation and growth potential of IESCs isolated from diet-induced obese compared with lean mice. ${ }^{3,19}$ Consistent with previous findings in rodents, ${ }^{3,19}$ our results showed that insulin and IGF-1 enhanced the proliferation of intestinal crypts (including IESCs and other crypt cells) in humans. This suggests that obesity-induced high levels of insulin and IGF-1 in the stem cell niche may impact IESC proliferation in obese humans via a similar mechanism as has been found in rodents and may drive abnormal proliferation as insulin resistance develops.

The degree of insulin and IGF-1-induced increases in proliferation differed (Figure 1(a) and (b)). It is likely that the varied effect reflects differences in the ligand-receptor binding affinity and signaling between insulin and IGF-1. The three highly homologous tyrosine kinase receptors by which insulin and IGF-1 mediate their biological effects, insulin receptor isoform A (IRA), insulin receptor isoform $B$ (IRB), and IGF-1 receptor (IGF-1R), are expressed in IESCs. ${ }^{3}$ Both insulin and IGF-1 are able to bind to each receptor, albeit at different affinities, and IR and IGF-1R can also form heterodimers that modulate the selectivity and affinity for insulin and IGF-1 in activating downstream signaling molecules. ${ }^{22}$ Moreover, IGF-1, but not insulin,
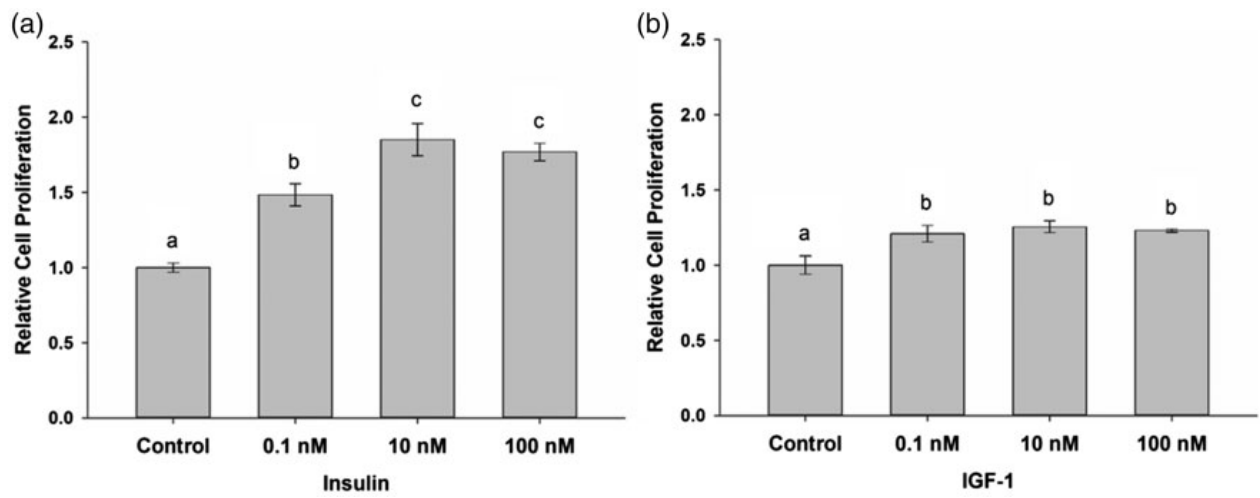

Figure 1. Cell proliferation in response to insulin (a) or IGF-1 (b). Data are expressed as Mean \pm SEM of fold change relative to the control group ( $n=4$ ). Means with different letters indicate significant differences, $P<0.05$. 

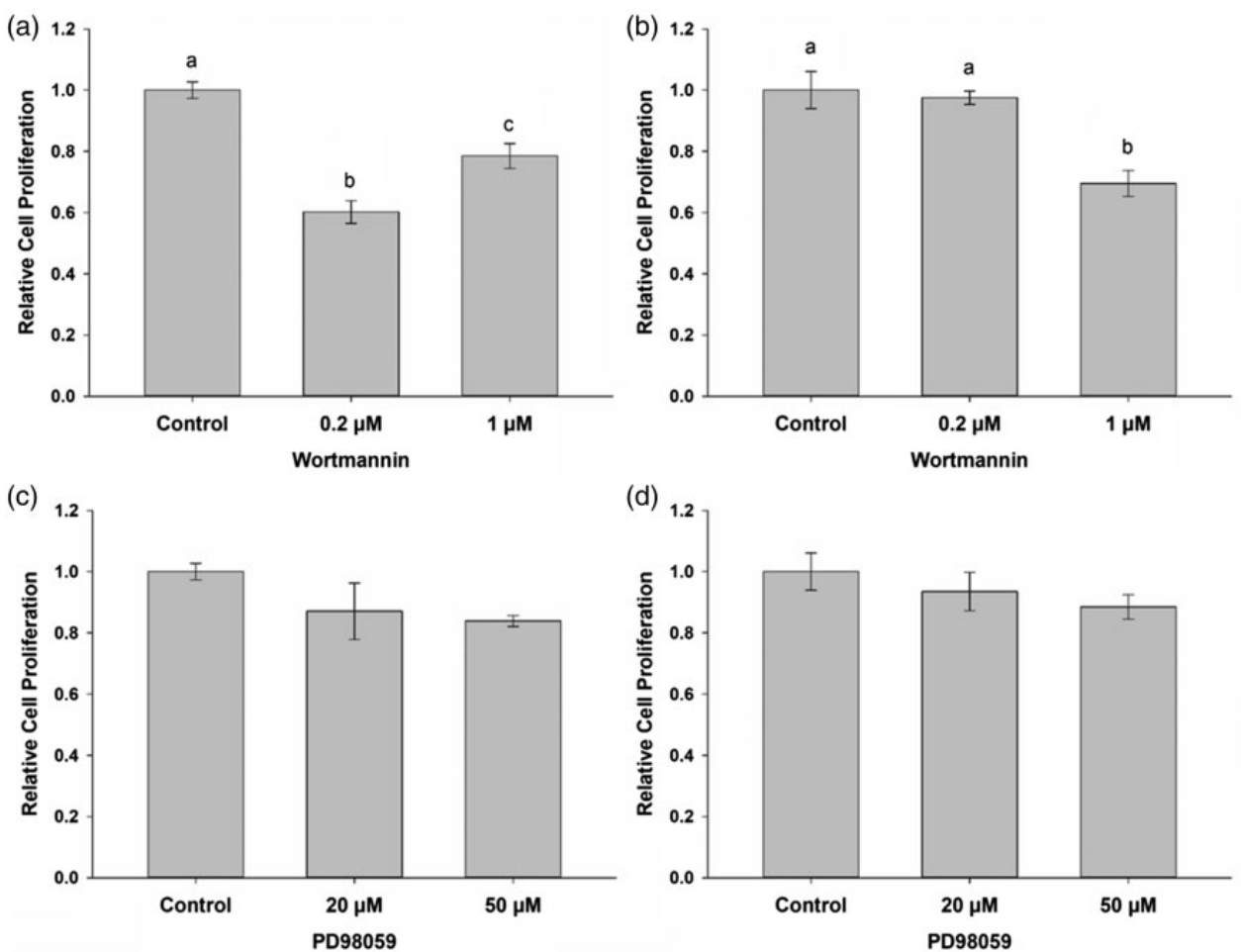

Figure 2. The effect of Wortmannin on insulin-induced (a) or IGF-1-induced (b) proliferation, and the effect of PD98059 on insulin-induced (c) or IGF-1-induced (d) proliferation. Data are expressed as Mean \pm SEM of fold change relative to the control group $(n=4)$. Means with different letters indicate significant differences, $P<0.05$.
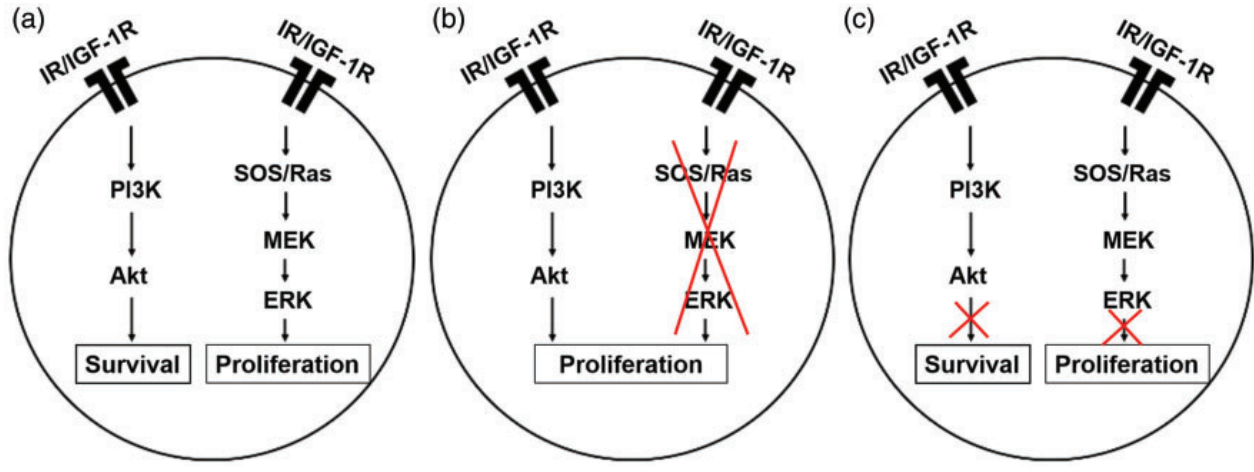

Figure 3. Proposed mechanisms of insulin receptor (IR) and IGF-1 receptor (IGF-1R)-mediated proliferation of IESCs under normal and resistant states. (a) A balance between the PI3K-dependent pathway regulating nutrient flow for cell survival and the ERK-dependent pathway regulating cell proliferation determines the cellular response to insulin and IGF-1 under normal conditions. (b) An imbalance in signaling between the two pathways may result in an uncoupling of the control mechanism between survival and proliferation in IESCs and lead to abnormal tissue renewal and function. (c) Inactivation of PI3K and/or ERK signaling molecules may induce insulin and IGF-1 resistance in IESCs and result in abnormal tissue renewal and function.

binds to IGF binding proteins (IGFBPs) in circulation; thus, the actions of IGF-1 are inhibited by IGFBPs, while insulin is not affected. ${ }^{29}$ In addition, a variety of receptor substrates and signaling molecules have been identified to be differentially activated by insulin or IGF- $1 .^{30}$ Taken together, these differences in the ligand-receptor binding affinity and signaling molecules between insulin and IGF-1 may contribute to their differential effects on metabolism and proliferation.

Insulin and IGF-1 receptor resistance is a hallmark of obesity, and insulin and IGF-1 receptor resistance in other tissues or organs (e.g. adipose tissue, liver) has been known to be driven by high levels of insulin and IGF-1.132 It is traditionally thought that there is a balance between two downstream insulin and IGF-1 receptor signaling pathways, the PI3K-dependent pathway regulating nutrient flow for cell survival, and the ERK-dependent pathway regulating cell proliferation ${ }^{22}$ (Figure $3(\mathrm{a})$ ). The balance between these two pathways determines the cellular response to insulin and IGF- $1 .{ }^{33}$ Contrary to this traditional thought, we found that insulin and IGF-1 induced an increase in the proliferation of crypts isolated from obese humans through the PI3K pathway, and not the classical ERK mitogenic pathway (Figure 3(b)). An activation of PI3K signaling is known to prevent the action of cell cycle inhibitors (e.g. p21Cip1/WAF, ${ }^{34}$ p27(kip1) ${ }^{35}$ ) and inhibits 
pro-apoptotic proteins (e.g. Bcl-2-associated death promoter (BAD), ${ }^{36}$ caspase- $9^{37}$ ), and regulates the activity of a variety of transcription factors (e.g. Forkhead family of transcription factors (FoxO), murine double minute 2 $(\mathrm{Mdm} 2))^{37}$ that are responsible for the transcription of pro- and anti-apoptotic genes. An obesity-induced increase in PI3K signaling and activation of these mechanisms may not only increase proliferation, but lead to a greater chance of mutation or less DNA repair, which causes an increased cancer risk. ${ }^{4-6}$

Authors' contributions: WZ and MJD conceived and designed research; BMR supplied human tissues; WZ performed experiments; WZ analyzed data; WZ and MJD interpreted data; WZ generated figures; WZ and MJD drafted manuscript; all authors were involved in editing and revising the manuscript, and had final approval of the submitted and published versions.

\section{DECLARATION OF CONFLICTING INTERESTS}

The author(s) declared no potential conflicts of interest with respect to the research, authorship, and/or publication of this article.

\section{FUNDING}

The author(s) disclosed receipt of the following financial support for the research, authorship, and/or publication of this article: This work was supported by National Institute of Food and Agriculture (grant number ILLU-538-926).

\section{ORCID iD}

Weinan Zhou (D) http:// orcid.org/0000-0001-9323-900X

Megan J Dailey (D) http:// orcid.org/0000-0003-4587-2307

\section{REFERENCES}

1. Dailey MJ. Nutrient-induced intestinal adaption and its effect in obesity. Physiol Behav 2014;136:74-8

2. Beyaz S, Mana MD, Roper J, Kedrin D, Saadatpour A, Hong SJ, Bauer-Rowe KE, Xifaras ME, Akkad A, Arias E, Pinello L, Katz Y, Shinagare S, Abu-Remaileh M, Mihaylova MM, Lamming DW, Dogum R, Guo G, Bell GW, Selig M, Nielsen GP, Gupta N, Ferrone CR, Deshpande V, Yuan GC, Orkin SH, Sabatini DM, Yilmaz OH. High-fat diet enhances stemness and tumorigenicity of intestinal progenitors. Nature 2016;531:53-8

3. Mah AT, Van Landeghem L, Gavin HE, Magness ST, Lund PK. Impact of diet-induced obesity on intestinal stem cells: hyperproliferation but impaired intrinsic function that requires insulin/IGF1. Endocrinology 2014;155:3302-14

4. Bielas JH, Heddle JA. Proliferation is necessary for both repair and mutation in transgenic mouse cells. Proc Natl Acad Sci U S A 2000;97:11391-6

5. Tomasetti C, Vogelstein B. Cancer etiology. Variation in cancer risk among tissues can be explained by the number of stem cell divisions. Science 2015;347:78-81

6. Comaills V, Kabeche L, Morris R, Buisson R, Yu M, Madden MW, LiCausi JA, Boukhali M, Tajima K, Pan S, Aceto N, Sil S, Zheng Y, Sundaresan $\mathrm{T}$, Yae $\mathrm{T}$, Jordan NV, Miyamoto DT, Ting DT, Ramaswamy S, Haas W, Zou L, Haber DA, Maheswaran S. Genomic instability is induced by persistent proliferation of cells undergoing epithelial-to-mesenchymal transition. Cell Rep 2016;17:2632-47
7. Bjorge T, Tretli S, Engeland A. Height and body mass index in relation to cancer of the small intestine in two million Norwegian men and women. Br J Cancer 2005;93:807-10

8. Bardou M, Barkun AN, Martel M. Obesity and colorectal cancer. Gut 2013;62:933-47

9. Yanai H, Atsumi N, Tanaka T, Nakamura N, Komai Y, Omachi T, Tanaka K, Ishigaki K, Saiga K, Ohsugi H, Tokuyama Y, Imahashi Y, Ohe S, Hisha $\mathrm{H}$, Yoshida $\mathrm{N}$, Kumano $\mathrm{K}$, Kon $\mathrm{M}$, Ueno $\mathrm{H}$. Intestinal stem cells contribute to the maturation of the neonatal small intestine and colon independently of digestive activity. Sci Rep 2017;7:9891

10. Barker N, Ridgway RA, van Es JH, van de Wetering M, Begthel $H$, van den Born M, Danenberg E, Clarke AR, Sansom OJ, Clevers H. Crypt stem cells as the cells-of-origin of intestinal cancer. Nature 2009;457:608-11

11. Baker AM, Cereser B, Melton S, Fletcher AG, Rodriguez-Justo M, Tadrous PJ, Humphries A, Elia G, McDonald SA, Wright NA, Simons BD, Jansen M, Graham TA. Quantification of crypt and stem cell evolution in the normal and neoplastic human colon. Cell Rep 2014;8:940-7

12. Kageyama H, Kageyama A, Endo Y, Osaka T, Nemoto K, Hirano T, Namba Y, Shioda S, Inoue S. Ventromedial hypothalamus lesions induce jejunal epithelial cell hyperplasia through an increase in gene expression of cyclooxygenase. Int J Obes Relat Obes 2003;27:1006-13

13. Mayer J, Yannoni CZ. Increased intestinal absorption of glucose in three forms of obesity in the mouse. Am J Physiol 1956;185:49-53

14. Verdam FJ, Greve JW, Roosta S, van Eijk H, Bouvy N, Buurman WA, Rensen SS. Small intestinal alterations in severely obese hyperglycemic subjects. J Clin Endocrinol Metab 2011;96:E379-83

15. Balint JA, Fried MB, Imai C. Ileal uptake of oleic acid: evidence for adaptive response to high fat feeding. Am J Clin Nutr 1980;33:2276-80

16. Ferraris RP, Vinnakota RR. Intestinal nutrient transport in genetically obese mice. Am J Clin Nutr. 1995;62:540-6

17. Singh A, Balint JA, Edmonds RH, Rodgers JB. Adaptive changes of the rat small intestine in response to a high fat diet. Biochim Biophys Acta 1972;260:708-15

18. Winesett DE, Ulshen MH, Hoyt EC, Mohapatra NK, Fuller CR, Lund PK. Regulation and localization of the insulin-like growth factor system in small bowel during altered nutrient status. Am J Physiol 1995;268:G631-40

19. Van Landeghem L, Santoro MA, Mah AT, Krebs AE, Dehmer JJ, McNaughton KK, Helmrath MA, Magness ST, Lund PK. IGF1 stimulates crypt expansion via differential activation of 2 intestinal stem cell populations. FASEB J 2015;29:2828-42

20. Muniyappa R, Sowers JR. Role of insulin resistance in endothelial dysfunction. Rev Endocr Metab Disord 2013;14:5-12

21. Carlson CJ, Koterski S, Sciotti RJ, Poccard GB, Rondinone CM. Enhanced basal activation of mitogen-activated protein kinases in adipocytes from type 2 diabetes: potential role of p38 in the downregulation of GLUT4 expression. Diabetes 2003;52:634-41

22. Boucher J, Kleinridders A, Kahn CR. Insulin receptor signaling in normal and insulin-resistant states. Cold Spring Harb Perspect Biol 2014;6:a009191

23. Sato T, Stange DE, Ferrante M, Vries RG, Van Es JH, Van den Brink $S$, Van Houdt WJ, Pronk A, Van Gorp J, Siersema PD, Clevers H. Longterm expansion of epithelial organoids from human colon, adenoma, adenocarcinoma, and Barrett's epithelium. Gastroenterology 2011;141:1762-72

24. Mahe MM. Sundaram N, Watson CL, Shroyer NF, Helmrath MA. Establishment of human epithelial enteroids and colonoids from whole tissue and biopsy. J Vis Exp 2015;97:52483

25. Lu CC, Chu PY, Hsia SM, Wu CH, Tung YT, Yen GC. Insulin induction instigates cell proliferation and metastasis in human colorectal cancer cells. Int J Oncol 2017;50:736-44

26. Chan MT, Lim GE, Skovsø S, Yang YH, Albrecht T, Alejandro EU, Hoesli CA, Piret JM, Warnock GL, Johnson JD. Effects of insulin on human pancreatic cancer progression modeled in vitro. BMC Cancer 2014;14:814

27. Svegliati-Baroni G, Ridolfi F, Di Sario A, Casini A, Marucci L, Gaggiotti G, Orlandoni P, Macarri G, Perego L, Benedetti A, Folli F. Insulin and 
insulin-like growth factor-1 stimulate proliferation and type I collagen accumulation by human hepatic stellate cells: differential effects on signal transduction pathways. Hepatology 1999;29:1743-51

28. Frystyk J, Skjaerbaek C, Vestbo E, Fisker S, Orskov H. Circulating levels of free insulin-like growth factors in obese subjects: the impact of type 2 diabetes. Diabetes Metab Res Rev 1999;15:314-22

29. Werner H, Weinstein D, Bentov I. Similarities and differences between insulin and IGF-I: structures, receptors, and signalling pathways. Arch Physiol Biochem 2008;114:17-22

30. Dupont J, LeRoith D. Insulin and insulin-like growth factor I receptors: similarities and differences in signal transduction. Horm Res 2001;2:22-6

31. Renstrom F, Buren J, Svensson M, Eriksson JW. Insulin resistance induced by high glucose and high insulin precedes insulin receptor substrate 1 protein depletion in human adipocytes. Metab Clin Exp 2007;56:190-8

32. Catalano KJ, Maddux BA, Szary J, Youngren JF, Goldfine ID, Schaufele F. Insulin resistance induced by hyperinsulinemia coincides with a persistent alteration at the insulin receptor tyrosine kinase domain. PLoS One 2014;9:e108693
33. Aksamitiene E, Kiyatkin A, Kholodenko BN. Cross-talk between mitogenic Ras/MAPK and survival PI3K/Akt pathways: a fine balance. Biochem Soc Trans 2012;40:139-46

34. Zhou BP, Liao Y, Xia W, Spohn B, Lee MH, Hung MC. Cytoplasmic localization of p21Cip1/WAF1 by Akt-induced phosphorylation in HER-2/neu-overexpressing cells. Nat Cell Biol 2001;3:245-52

35. Motti ML, De Marco C, Califano D, Fusco A, Viglietto G. Aktdependent T198 phosphorylation of cyclin-dependent kinase inhibitor p27kip1 in breast cancer. Cell Cycle 2004;3:1074-80

36. Datta SR, Dudek H, Tao X, Masters S, Fu H, Gotoh Y, Greenberg ME. Akt phosphorylation of BAD couples survival signals to the cellintrinsic death machinery. Cell 1997;91:231-41

37. Cardone MH, Roy N, Stennicke HR, Salvesen GS, Franke TF, Stanbridge E, Frisch S, Reed JC. Regulation of cell death protease caspase-9 by phosphorylation. Science 1998;282:1318-21

(Received February 7, 2018, Accepted June 4, 2018) 